Evy Beate Stykket

Universitetet i Søraust Noreg

\title{
«Han har da ei Lærebygning» Aasmund Olavsson Vinje sitt syn på Knud Knudsen i Dølen
}

\begin{abstract}
"He was a teaching giant": Aasmund Olavsson Vinje’s Approach to Knut Knudsen in Dølen
Knud Knudsen (1812-1895) and Aasmund O. Vinje (1818-1870) were two prominent Norwegian figures in the nineteenth century. Although they are both frequently mentioned in various books and texts about Norwegian language history, there are no studies focusing on a comparison of the two of them. They had strong opinions on various topics and often participated in public debates. In addition to this, they are intertwined with the early development of what later became the two Norwegian written languages: bokmål and nynorsk. Vinje is usually associated with what later became nynorsk, while Knudsen is a part of the history of bokmål. This dichotomy, however, obscures some of the details in the relationship between these two very complex men. The aim of this article is to share some nuances in the relationship between the two of them and to discuss their differences and similarities.
\end{abstract}

Keywords: Knud Knudsen, Aasmund O. Vinje, Norwegian language history, language planning, school history

Nøkkelord: Knud Knudsen; Aasmund O. Vinje; språkhistorie, skriftspråk, språkpolitikk, skolehistorie

\section{Innleiing}

Knud Knudsen (1812-1895) og Aasmund O. Vinje (1818-1870) var to sentrale skikkelsar i den språkhistoriske debatten på 1800-talet. Dei fekk kvar for seg mykje å seie for utviklinga av både dansk-norsken (bokmålet) og landsmålet (nynorsken); Knudsen som reformator av det danske skriftspråket og Vinje som nyskapande journalist og essayist innanfor landsmålet. Sjølv om dei to ofte blir skildra i dei same tekstane om språkhistoriske tema, finst det ikkje noko samla oversikt over dei to i forhold til kvarandre. Denne artikkelen har som mål å nyansere forholdet mellom dei ved å løfte dei ut av den vanlege dikotomien med landsmål og dansk-norsk. 
Heilt frå midten av 1800-talet, da to ulike retningar mot eit norsk skriftspråk blei sett på som reelle alternativ, har denne delen av norsk språkhistorie blitt framstilt som nettopp det: To vegar; to skriftspråk; to ulike syn; og med to resultat: bokmål og nynorsk. Eit mykje bruka sitat for å underbygge denne todelinga, er henta frå ein artikkel av Knud Knudsen (1812-1895), Om Norskhed $i$ vor Tale og Skrift (1850), der han skriv at «desse to vegane til eit verkeleg norsk språk er forresten bare ulike når det gjeld utgangspunktet og den første strekninga» ${ }^{1}$.

Denne dikotomien er god å halde seg til både av historiske og pedagogiske årsaker. Sentrale språkdebattantar blir gjerne plassert i ein av dei to kategoriane; dei som heldt seg til eit skriftspråk som tok utgangspunkt i dei norske dialektene, og dei som heldt seg til eit skriftspråk som tok utgangspunkt i dansk. Sjølv om nyansane i begge kategoriane er mange, er det ei ofte uuttalt line mellom dei to leirane, slik at ein person anten høyrer til den eine eller den andre. Dermed kan ein stå i fare for å gå glipp av detaljar som best blir lagt merke til når ein ser på personar eller hendingar meir synkront i forhold til kvarandre og lausrive frå denne todelinga.

I denne artikkelen vil eg sjå på to personar som blir assosiert med kvart sitt skriftspåk: Aasmund O. Vinje (1818-1870) og Knud Knudsen (1812-1895). Vinje var «ein banebrytar for utviklinga av ein journalistisk og essayistisk stil på landsmål» (Torp og Vikør 2014: 186). Knudsen var reformatoren som «sette inn krefter på å skipe eit norsk språk som skilde seg klart frå dansk» (Otnes og Aamotsbakken 2017: 139). Dei blir dermed del av kvar si historie: historia om nynorsken og historia om bokmålet, og dei blir forklart ut frå den konteksten. I gjennomgangen i denne artikkelen vil eg prøve å sjå dei to i samanheng med kvarandre først og fremst, og formålet er som sagt å bidra til å nyansere forholdet mellom dei to.

\section{Tidlegare forsking}

Sjølv om det ikkje er gjort eigne studiar for å samanlikne Vinje og Knudsen og utviklinga i forholdet mellom dei, for seg, er dei ofte nemnt i same tekstar om ulike språkpolitiske tema frå 1800-talet. I tillegg er dei del av kvarandres biografiar. I bl.a. Olav Vesaas sin biografi om Vinje, A.O. Vinje - ein tankens hoermann (Vesaas 2018), er Knudsen ein spesielt viktig aktør i kapittelet som heiter Språkstrid og teaterstrid, og han blir også nemnt fleire gonger som ein av dei Vinje var mykje saman med. Blant anna får Vesaas fram at Knudsen og Vinje lenge hadde same språksyn (Vesaas 2018: 172), men i samband med at Vesaas fortel om stiftinga av Det norske Selskab i 1859, nemner han også Vinje si vegring mot å «hamne i ein bås» (Vesaas 2018: 198), og at Vinje på det tidspunktet hadde forlate fornorskingslina til Knudsen. Knudsen

Alle sitat frå gamle tekstar er oversatt til moderne nynorsk av meg for å lette lesinga. Originaltekstane vil bli satt inn i fotnoter slik som her. «Disse to Veje til et virkeligt norsk Sprog er forresten kun forskjellige, hvad Udgangspunktet og den første Strækningen angaar». 
blir ikkje nemnt av Vesaas i samband med det siste tiåret i livet til Vinje mellom 1860 og til han døydde i 1870.

I 1938 kom Sigmund Skard med avhandlinga A.O. Vinje og antikken (Skard 1938). Her er det godt kartlagt korleis forholdet mellom Knudsen og Vinje var når det gjeld dei klassiske språka og undervisninga av dei i skulen. Om ein skal snakke om noko brot mellom dei to i denne saka, finn me det fyrste hintet om noko slikt i 1853 ifølge Skard (Skard 1938: 188) då Vinje skriv ein artikkel som ikkje utelukkande stør synet til Knudsen.

I bibliografien om Knud Knudsen som er skriven av Egil Børre Johnsen, Unorsk og norsk, blir Vinje nemnt med jamne mellomrom, men forholdet blir ikkje gått mykje inn i (Johnsen 2006). Johnsen kjem likevel med nokre generelle kommentarar, til dømes når han nemner at Vinje «tidvis kunne se med mild overbærenhet på Knudsens målstrev» (Johnsen 2006: 222). I samband med ein polemikk i 1865 kommenterer Johnsen at «Vinje var en motpart, men en motpart som aldri virkelig ble sint på Knudsen, like lite som Knudsen ønsket å overfalle Vinje» (Johnsen 2006: 363). For å nyansere dette tilsynelatande gode forholdet mellom dei to, viser Johnsen til to artiklar der Vinje skal ha vore brutal mot Knudsen og kalla han «du vesle k-en min» (Johnsen 2006: 222). Eg meiner at artiklane Johnsen her viser til, ikkje er retta mot Knudsen, men mot ein anonym innsendar til Dølen som signerte tekstane sine med «k». Dei innsendte tekstane strir på alle vis med haldningane til Knudsen, og tilsvaret frå Vinje er, slik eg ser det, ikkje retta mot Knudsen, men mot ein annan $« \mathrm{k} »^{2}$.

I tillegg til dei tre verka eg har trekt fram her, er det mange større og mindre tekstar der Vinje og Knudsen er aktørar samtidig, til dømes i innføringsbøker i språkhistorie (bl.a. Hovuddrag i norsk språkhistorie (Torp og Vikør 2014); Tekst $i$ tid og rom (Otnes og Aamotsbakken 2017); Språk og samfunn gjennom tusen år (Almenningen mfl. 1981)), tematiske studiar (bl.a. Språk og nasjon 1739-1868 (Hyvik 2009); Nasjonalisme i norsk språkstrid (Hoel 1996), A.O. Vinje og antikken (Skard 1938)); samt andre bibliografiske tekstar.

\section{Bakgrunn og utval}

Bakgrunnen for denne artikkelen var ein konferanse om Vinje hausten 2018. Eg hadde der eit føredrag om dei stadene i avisa Dølen (1858-1870) der Knud Knudsen blir nemnt. Det er ein gjennomgang som ikkje har blitt gjort andre stader.

2 Innlegga signert «k» gjeld ei litteraturanmelding i Illustrert Nyhedsblad i $1866 \mathrm{der}$ «k» skriv ei anmelding av ei bok. Han vender seg blant anna til dei som «lytte til de høirøstet og hyppig forekommende Paastande om, at vort Folk i sin heelhed er fremmed for vort nuværende Skriftsprog og dannede Talesprog» (Johnsen 2006: 135). For å bruke uttrykksmåten til «k», er vel Knud Knudsen ein av dei som kjem med høgrøsta og hyppige påstandar om nettopp dette, så det er usannsynleg at han sjølv ville ha skrive om målsaka på den måten 
Sidan har eg utvida blikket litt og også trekt inn fleire kjelder, men treffpunkta i Dølen er framleis eit berande element i denne artikkelen. Fokus er på perioden etter 1858 då Dølen var etablert.

Artikkelen er strukturert etter dei temaa som blir adressert dei gongene Vinje nemner Knudsen i Dølen, og tidsrommet er derfor fyrst og fremst 1858 til Knudsen blir nemnt i Dølen siste gong i 1868. Dette blir ikkje ei fullstendig oversikt over forholdet mellom dei to ettersom dei begge to hadde ein voldsam tekstproduksjon, og det hadde blitt for omfattande å hente inn alt dei skriv om kvarandre.

Eg har bruka faksimileutgåva til Reidar Djupedal av Dølen, og når eg brukar sitat derifrå viser eg til sidetal ved å først skrive anten band I, II eller III for så å skrive sidetal og spalte a, b eller c; t.d. (Vinje 1972: I 1a)

\section{Gjennomgang}

Aasmund Olavsson Vinje stifta avisa Dølen i 1858 for å «tala med folk om eitt og anna som [låg]han på hjartet ${ }^{3} »$ (Vinje 1972: I 1a). Når eg tek utgangspunkt i artiklar frå denne avisa, startar eg dermed på Vinje sin heimebane der han sjølv er redaktør og styrer kven som får sleppe til og få ordet. Nokre få gonger står det artiklar på trykk signert Knud Knudsen. Det skjer aldri utan ein lang kommentar frå Vinje i forkant.

\section{Skulepolitikk}

Gjennom store delar av 1800-talet var det stor diskusjon om innhaldet i skulen, med ein spesielt intens debatt frå rundt 1830 til rundt 1860. Diskusjonen handla mykje om rolla til dei klassiske språkfaga i skulen. Debatten har i ettertid gjerne blitt skildra som ein kamp mellom humanistar og realistar, og mellom to ulike syn på danning. På den eine sida: det nyhumanistiske synet med vekt på dei klassiske språka si evne til formaldanning, og på den andre sida: det realpedagogiske synet som hadde sine røter i opplysningstidas tru på «nyttig» kunnskap (Hertzberg 1995: 40).

Knud Knudsen var ein markant debattant for det realpedagogiske synet, og i praksis vil det seie at han argumenterte mot gresk og latin i skulen og for meir morsmålsundervisning tidleg. Grunngjevinga hans var ofte tufta på eigne erfaringar i klasserommet: Det var vanskeleg å læra latin og gresk når ein ikkje fyrst hadde lært å skrive sitt eige morsmål.

Fyrste gongen Knudsen blir nemnt i Dølen, er i samband med ein artikkel som heiter «Hartvig Nissen som Storthingsmann», trykt sundag 27. mars 1859. Nissen var blant dei som ønskte reform i skulen, og han sto på same side som

3 «tala med Folk om Eit og Annat, som [låg] honom på Hjartat». 
Vinje og Knudsen når det gjaldt å oppjustere talet på undervisningstimar i norsk og nedjustere talet på undervisningstimar i gresk og latin. Vinje skriv: «Nest etter overlærer K. Knudsen var han kanskje den første som såg at det er villmannsskap å la små barn slita seg ut på latin før dei kan morsmålet eller nyare, enklare språk som tysk, fransk og engelsk» (Vinje 1972: I 90 b) 4 $^{4}$ I eit tillegg ein månad seinare skriv han: «Folk som løfter fram slike tankar er som fyrtårn i folkehavet» (Vinje 1972: I 108 c) $)^{5}$.

Vinje understrekar her den anerkjenninga han meiner at Knudsen, og fleire med han, fortener ettersom dei står som fyrtårn i folkehavet når det gjeld å ta til orde mot latinmonopolet. Det er likevel ikkje slik at Vinje utelukkande støtta Knudsen i saka om klassiske språk i skulen. Haldninga til dei klassiske språka i skulen var i endring, både i samfunnet og også hos Vinje. Sigmund Skard (1938) har ein gjennomgang av denne utviklinga hos Vinje, i boka A.O. Vinje og antikken: Studier i norsk åndshistorie, og han formulerer det samansette synet til Vinje blant anna slik:

Han strider på den eine sida mot latinskulen med realistiske og nasjonale argument, i jambreidd med menn som Aasen, Knudsen og Vig, [...] han kann på andre sida gå mot desse same partibrørne sine, med argument som kann synast lånte frå hans og deira argaste motmenn. Det er tvillaust at desse nye draga i tankegangen hans høyrer inn i ein tidshistorisk samanheng (Skard 1938: 185).

Skryt av dei som sto som fyrtårn mot latinmonopolet kan altså ikkje tolkast slik at Vinje stør Knudsen fullt ut $i$ all hans argumentasjon mot latin i skulen, men at dei deler nokre standpunkt. To år tidlegare (1857) hadde dei diskutert skulepolitikk og timefordelinga mellom dei ulike språka i skulen; først og fremst dei klassiske språka latin og gresk på ei side mot norsk på andre sida, men engelsk, tysk, fransk og gammalnorsk var også språk som blei nemnt i diskusjonen. Knudsen sto i sin kamp mot latin, medan Vinje i større grad sto for ei sameining mellom klassisk og norsk i innlegga sine i 1857 (Skard 1938: 192).

Frå og med 1858 ser ein derimot, framleis ifølge Sigmund Skard, ei dreiing der kampen mot latinmonopolet får større rom i artiklane til Vinje, og motsetnaden mot Knudsen og norskdomsstrevarane blir mindre tydeleg (Skard 1938: 200). Ein skilnad mellom dei to var likevel at Vinje ikkje bare uttalte seg mot latin, men for gammalnorsk i skulen, for eksempel når han i programartikkelen i første utgåve av Dølen skriv at det er «spott og spe at lærarar, prestar, dommarar og alle andre tenarar i staten lærer så mykje, men ikkje det språket som våre fedre snakka, eller

4 «Næst etter Overlærar K. Knudsen er han kanskje den fyrste, som saa, at det var Villmannskap at lata Smaaborn slita seg ut paa Latin, fyrren dei kjende til Modersmaal eller nyare og lettare Maal, som Tysk, Fransk og Engelsk».

5 «Folk, som bera slike Tankar fram ere som Vitvarder i Folkehavet» (Vinje sin skrivemåte av det samansette ordet vete + varde, altså ein bålvarde. Skrivemåten går tilbake på norrønt «viti»). 
det som folket snakkar» (Vinje 1972: I 2 b) ${ }^{6}$. Knudsen hadde òg kome med forslag om å undervise i gamalnorsk i norsk skule, men ikkje så omfattande som det Vinje etter kvart ønskte seg.

Hovudteksten til Knudsen når det gjeld denne saka, er boka Latinskole uten Latin (1884). Den kom rett nok ikkje før i 1884, men haldningane til Knudsen på dette punktet endra seg mindre enn hos Vinje i løpet av dei åra. I denne boka har han ein gjennomgang av argumenta til fleire av motstandarane sine; dei får kvar sine små kapittel der han går gjennom argumentasjonen deira, som han så kommenterer. Sistemann ut er Vinje (skalden «Dølen») (Knudsen 1884: 58). Knudsen startar med å sitere eit argument frå Vinje som dei er einige om, som gjeld omsettingar. Vinje blir sitert slik: «Kvart språk er så rikt, at det er i stand til å referere meining og tanke frå eit anna språk [...] så når folk snakkar om at det ikkje kan omsettast, så er ikkje dette heilt sant» (Knudsen 1884: 58) ${ }^{7}$. Samtidig blir Vinje også sitert på at «dei nyare litteratar har ingenting som er så fullstendig i form og tanke og følelsesliv som det beste hos dei eldre» (Knudsen 1884: 59) til denne tilsynelatande sjølvmotseiinga skriv Knudsen at «Dølen var elles, som hans lesere vet, i ulike ting litt løs av seg» ${ }^{9}$ og han kunne derfor veksle mellom ulike syn. Kapittelet om Vinje blir avslutta med eit sitat der Vinje ifølge Knudsen er i ein tilstand der han «kunne si latinstreverne noen sannheter som måtte svi som salt i sure øyne» ${ }^{10}$. Dermed blir gjennomgangen av samtlege motstandarar for Knudsen avslutta med at Vinje får siste ordet imot latinstreverne, på same lag som Knudsen.

Ein annan del av skulepolitikken gjaldt eksamensform i høgare utdanning, og i 1865 får Knudsen ein ny runde med skryt frå Vinje som skriv at Knudsen har «vore ute før andre med sitt framsyn» (Vinje 1972: II 151b) ${ }^{11}$. Denne gongen gjeld kommentaren til Vinje ein tekst av Knudsen som sto i tidsskriftet Norden. Saka handla om deling av embetseksamen (universitetseksamen som var obligatorisk for visse stillingar og embete). Kort fortalt handla det om at ein i avsluttande embetseksamen skulle prøvast i fleire ulike tema, men ikkje i morsmål. Knudsen meinte for det fyrste at ein måtte inkludere morsmålet $\mathrm{i}$ embetseksamen, og for det andre (og det er dette Vinje refererer til) at ein som student måtte få velje seg ut nokre tema og ikkje bli eksaminert i alt (Dahl 1962: 121) ${ }^{12}$. For Knudsen hang dette saman

6 «Spott og Spe, at Skolelærarar, Prestar, Domarar og alle andre Statens Tenarar (Tjenere) læra so ugrunneleg mykit, men ikki det Maal vore Fædre talade og det, som Folket talar».

7 «Kvert Tungemaal er saa rikt, at det er i Stand til at gjengjeva Meining og Tanke fraa eit annat Maal [...] so naar Folk tala um, at det og det ikkje kan oversetjas, so er ikkje dette fullsant».

8 «dei nyare Litter[atar]. hava ingen Ting so fullendt i Form og Tanke- og Følelsesliv som» (det beste i) «dei eldre».

9 «Dølen var elles, som hans læsere vet, i ømse ting noget løs av sig».

10 «kunde [...] sige latinstræverne sanheter, som måtte svie som salt i sure øjne».

11 «voret ute fyre andre med sitt Framsyn».

12 I skulelova frå 1845 sto det at ein ved filologisk embets- eller skulelærareksamen skulle prøvast i romersk og gresk filologi; historie; filosofi og filosofihistorie; samt hebraisk og gammalnorsk i tillegg. 
med all anna skulepolitikk - dersom ein skulle få til endring på grunnskulenivå, måtte ein også endre lærarutdanninga.

Som me alt har sett, er Vinje og Knudsen einige i auka morsmålsundervisning i skulen, og å få dette inn i lærarutdanninga er ei forlenging av det. Men i tillegg så handlar dette om auka fleksibilitet i skulen. Alle treng ikkje lære det same. Vinje hadde ivra for dette i ulike samanhengar, blant anna når han skriv i Dølen (nr. 22 1870 ) at «ombodsmenn og mekanikarar av alle slag greier seg med omsettingar frå dei gamle, og i tillegg ved å kjenne den nye litteraturen og sine eigne studieretningar. Dei når ikkje lenger fram $»^{13}$. Eit lite apropos til dette er at diskusjonen om innhaldet i ulike studieretningar har me framleis i dag; skal alle lære det same, eller skal ein spesialisere seg meir i ein studieretning? Retorikken med at enkelte ikkje «når lenger fram» blir ikkje lenger bruka, men elles er bakgrunnen for diskusjonen ganske lik.

\section{Målsaka}

Vegen fram mot eit norsk skriftspråk er ein gjennomgåande diskusjon mellom Knudsen og Vinje, og eg skal sjå på korleis dei definerer seg sjølve i forhold til kvarandre innanfor dette temaet. Me startar med ein artikkel av Vinje frå 1859 for å sjå litt på kva Vinje meinte om språkføringa til Knudsen. Igjen blir Knudsen nemnt i forbifarten når Vinje skriv om nokon andre. Denne gongen er det deira felles gode ven, skule- og opplysningsmannen Ole Vig som er tema. Vinje skriv ein artikkel til minne om Vig som gjekk bort to år tidlegare, og Knudsen blir nemnt på denne måten:

Og liksom [Ole Vig] i tanken sto midt mellom folket og dei lærde, slik var språket hans også ein mellomting. Ein kan kalle det ein mellom-norsk, ein norsk utan vitskap. Ikkje så tilfeldig som språket til Wergeland, men meir som Bjørnsons språk i «Arne», som ser ut til å gjennomføre den norske læra til overlærar Knudsen [...] (Vinje 1972: I 193b) ${ }^{14}$.

Det kan verke som ei sjølvmotseiing å seie at mellom-norsken var utan vitskap, og at den samtidig var eit resultat av Knudsens norske loere.

For å forstå kva Vinje meiner, må me sjå litt nærare på kva han meiner med omgrepet vitskap. Eit hint om kva han legg i omgrepet, finn me i eit seinare nummer av Dølen. I 1866 skriv Vinje ein avisartikkel om tidsskriftet Nordisk tidsskrift, og eit langt stykke av denne artikkelen tar for seg kvifor eit lite land som Noreg ikkje

13 «Ombodsmen og Mekanikere af alle Slag bergja seg med Oversettelser fraa dei Gamle og elles kjenna den nye Litt. og sine eigne Studiegreiner. Dei naa'kje lenger fram».

14 «Og liksom han [(Ole Vig)] i Tanken stod midt imillom Folket og dei lærde, soleides var hans Maal likeins ein Millomting. Det var ein Millom-Norsk, kann ein segja, ein Norsk utan Vitenskap, vel ikki so på Slump som Wergelands, men likare Bjørnsons no i 'Arne', som tykkjest gjennomføra Overlærar Knudsens norske Lære». 
avlar så store vitskapsmenn som dei større landa. Han seier blant anna at «generelle grunnsyn på vitskap og kunst må me få frå større folk». Unntaket er «reine heimeting, enten det er i historie, som hos professor Munch, eller i språk, som hos I. Aasen» (Vinje 1972: II 223b) ${ }^{15}$. Vinje meiner altså at Noreg hadde avla ordentlege vitskapsmenn innanfor historie og språk, fordi dei kom med bidrag på norske område som utanlandske vitskapsmenn ikkje kunne seie noko om på same måten. Det er fleire liknande sitat om vitskap hos Vinje, der han først og fremst koplar vitskap til originalitet, altså at om ein skal kalle noko for vitskap, så er det fordi ein kjem fram til ny og original kunnskap. I tillegg brukar Vinje ofte omgrepet vitskap i same åndedrag som omgrepet kunst. Dette er med på å understreke noko av det same - å vere ein god vitskapsmann handlar om noko av det same som å vere ein god kunstnar: Ein må skape noko nytt. Når Knudsen ønskjer å reformere dansken, er det dermed ikkje vitskap, for det bringer ikkje ny kunnskap fram i lyset.

Poenget her blir å trekke fram at å kalle språket til Knudsen for vitskapslaust ikkje betyr at Vinje meiner at det er kunnskapslaust eller dårleg arbeid. I ein annan kommentar same året skriv Vinje følgande i ein artikkel om Det norske theater: «Eg talar ikkje her om overlærar Knudsen, for han har i det minste ei lærebygning han, sjølv om han ikkje går langt nok» (Vinje 1972: I 125b). Knudsen var språkkonsulent ved teateret, og hjalp skodespelarane med å fornorske uttala si, og det er i dette språkarbeidet Vinje meiner at Knudsen har ei loerebygning.

Sjølve ordet loerebygning er ei fornorsking som Vinje bruka for ordet system. Vinje erstattar gjerne framandord med norske erstattarord, ofte med framandordet i parentes som forklaring, og loerebygning er forklart med ordet system i parentes for eksempel 3. juli 1859 (Vinje 1972: I 147b) ${ }^{16}$. Også Knudsen fører ordet loerebygning opp som erstattarord for system i ordboka si Unorsk og norsk (Knudsen 1881: 820). Vinje meinte altså at Knudsen har ei loerebygning, eit system som ligg til grunn for språkarbeidet sitt.

Den historiske konteksten her er dessutan at dette blir skrive tre år etter at Knudsen si Haandbog $i$ dansk-norsk sprogloere (1856) kom ut - ein solid grammatikk som representerte den eine av to sider av ein dragkamp som ein var midt oppe i på 1800-talet: Korleis skal ein grammatikk vere? I samtida var det ein generell diskusjon om utforminga av lærebøker i grammatikk, og Knudsen stilte seg i den «nye» tradisjonen som stamma blant anna frå dansken Hofsgård og spesielt Baden (Hovdhaugen, Karlson, Henriksen og Sigurd 2000: 75). I tillegg representerte læreboka hans noko nytt ved at inndelinga og argumentasjonen rundt setningslæra var ny. I vår moderne forståing av omgrepet vitskapleg, vil ein nok seie at i alle fall grammatikken til Knudsen kvalifiserer til å bli beskrive som ein vitskapleg og teoretisk grammatikk (Bleken 1956: s. 7). Men sjølv om ettertida kallar arbeidet til

15 «allmenne Grunnsyn paa Vitenskap og Kunst maa vi faa fraa det større Folk [...] reine Heimeting anten det no er i Histori sosom hjaa Professor Munch eller i Spraak som hjaa I. Aasen».

16 «sjå dessutan Bjørkli (2011) for bruken av avløysarord hos Vinje». 
Knudsen for vitskapleg, så er det ikkje sikkert at Vinje sin definisjon av omgrepet vil inkludere eit arbeid som brukar andre sine teoriar på eit språk som allereie var kjent. Ein kan ikkje seie at ein kjem fram til noko som er nytt og originalt slik Aasen og Munch gjorde, og dermed er det ikkje vitskapleg slik Vinje brukar ordet.

Det var fleire som peikte på mangelen på systematikk i ortografien til Knudsen, eit resultat av at han ville gå "gradvishetens vei». I samtida var det likevel mange som slutta seg til mange av forslaga hans (Hoel 1996: 192). Blant anna var Vinje sjølv ein av dei som bruka eit oppnorska dansk i tråd med forslaga til Knudsen, fram til han stifta Dølen i 1858 og starta å bruke landsmålet (Almenningen, Roksvold, Sundøy og Vikør 1981: 75). Skriftspråket til Vinje på eit landsmål som var i støypeskeia var heller ikkje alltid fast og konsekvent, så slik sett kan ein seie at dei begge to hadde ei pragmatisk haldning til at språket måtte brukast og formast. Det ligg heller ikkje noko i argumentasjonen her til Vinje som tyder på at han har problem med systematikken eller strategien til Knudsen. Det som er kjerna i argumentet til Vinje, er at dansk-norsken til Knudsen ikkje er vitskapleg fordi den ikkje har noko originalt, nytt og ekte ved seg, slik landsmålet hadde.

\section{To språk - to leirar?}

Om lag eit år tidlegare - vinteren 1858/1859 - hadde landsmålet, og spesielt Dølen, fått krass kritikk når det gjaldt språklege val (Hoel 1996: 280). Me er på eit punkt i språkhistoria der landsmålet tydlegare blir eit reelt skriftspråkleg alternativ (Hyvik 2009: 309). Som eit resultat av skriftspråka blei tydelegare delt i to ulike alternativ, blir også delinga i kva for side folk sto på, tydelegare i den offentlege debatten. Den 19 november 1865 skriv Vinje ein artikkel der han understrekar fellesskapet mellom alle språkfolk: «Det er den same grunntanken me har, om ein så går den eine eller den andre vegen ${ }^{17}$. Men i tillegg legg han til at ein må unngå galskap og påstandar om at ein har den fulle sannleik på si side. Det er Knudsen som har trigga denne understrekinga hos Vinje, og han forklarar det på denne måten:

[...] han kjempar for mykje mot oss som han kallar norsk-norske. [...] Kanskje Knudsen er inne på det rette, og kanskje eg og mange med meg. [...] Eg tenker stort om Knudsens lærdom og strev, og eg har alltid sagt at han har gjort meir for vår målsak og utvikling av mange ting enn kanskje mange trur (Vinje 1972: II 131ab) ${ }^{18}$.

\footnotetext{
«det er den sama Gruntanken vi hava; om so ein gjeng den eine Vegen og den andre ein annan». 18 «han strider vel sterkt imot os, som kan kallar Norsk-Norske. [...] Kanskje Knudsen er inne paa det rette, og kanskje eg og mange med meg er det. [...] Eg tenker stort om Knudsens Lærdom og Stræv, og eg har altid sagt, at han har gjort meir for vaar Maalsak og Omgjerd av mange Ting en kanskje nokon enno trur...»
} 
Det er mange fine ord om Knudsen i denne teksten, men likevel fell det Knudsen tungt for brystet, og det fører til eit langt tilsvar. Her takkar Knudsen for gode ord, men han tek også eit oppgjer med dei som prøver å «snakke bort det dansknorske Maalstræv»:

Dølen synes at tro, at jeg i «Lørdags-Aftenblad» har væltet mig ind på de Norsknorske [...] Men jeg har hverken nu eller før væltet mig ind paa Nogen. Derimot har «Nogen» oftere væltet sig ind paa mig og det Maalstræv, som jeg beyndte adskillige Aar (1845) før det norsknorske Stræv og «Landsmaalet» blev til, og som jeg siden har ført Ordet for (Vinje 1972: II 135a).

Han kjem dermed i møte med det poenget som også er Vinje sitt; nemleg at ein kjempar for den same saka. Dette er ei generell haldning frå dei begge to, og mest kjent er kanskje Knudsen sin ofte siterte tanke om eit felles mål, slik han formulerte det i artikkelen «Om Norskhed i vor Tale og Skrift» frå 1850: «Disse to veier til et virkelig norsk språk er forresten bare ulike når det gjelder utgangspunktet og den første strekningen. Siden løper de utvilsomt sammen ${ }^{19}$. I 1867 formulerte han det slik: «Alle våre målstrevere har det til felles, at de vil at Norges språk skal være norsk slik som Danmarks er danske, Sveriges svensk, Tysklands tysk, eller [...] om mulig enda betre; enda meir norsk og folkelig» (Knudsen 1867: 3$)^{20}$. Som eg viste til, argumenterer likevel Knudsen bare nokre veker tidligegare for at målet kanskje ikkje er så likt likevel, og at det eine utgangspunktet faktisk er betre enn det andre.

Poenget her er at Knudsen føler seg som ein pioner i målstrevar-samanheng, og han understrekar at det var han som gjekk i bresjen for denne kampen. Når han nå føler seg definert ut av dei som kom etter, blir han provosert. Vinje stiller «vi norsknorske» opp mot Knudsen og brukar dermed inndelinga i norsknorske og dansknorske som Knudsen står bak. Men Vinje forsterkar forskjellane og motstanden mellom dei på ein måte som Knudsen lar seg irritere over. Litt forenkla kan ein si at Knudsen meiner at dei to kategoriane norsknorsk og dansknorsk hadde begge høyrt til i målstrevarflokken. Nå fryktar Knudsen at dei norsknorske er i ferd med å kapre tittelen målstrevarar, etter at dei har velta seg inn over den kampen han starta.

Eg skal ikkje gå langt inn i ein diskusjon om skilleliner og nyansane mellom dei kven som høyrte til kor. Me nøyar oss her med å slå fast at Knudsen i 1865 blei provosert over å bli definert ut frå den store samlinga av det som både Vinje og Knudsen kalla målstrevarar - eit omgrep som nok endra seg over tid, og som eg ikkje har plass til å forfølge her. Det er likevel grunn til å understreke at reint ideologisk står Knudsen på utsida av landsmålsflokken. Hyvik (2009) meiner at Knudsen ikkje hadde nokon eigentleg ideologi slik landsmålet hadde det, og

19 «Disse to Veje til et virkeligt norsk Sprog er forresten kun forskjellige, hvad Udgangspunktet og den første Strækning angaar; siden løber de udentvivl saman».

20 «Alle våre målstrævere har det tilfælles, at de vil Norges mål skal blive således norsk, som Danmarks er dansk, Sveriges svensk, Tysklands tysk, eller [...] om mueligt enda betre, ænnu mere norsk og folkeligt». 
han skriv om reformlinja at den «hadde rett og slett ikkje i seg ideologisk krutt til å fenge breitt» (Hyvik 2009: 375). Hyvik viser også til at landsmålet seinare stramma til ideologien om tokulturlæra på 60-talet slik at Knudsen tok meir avstand frå det (fordi det kunne skade hans eige språkprosjekt), samtidig som han la meir vekt på skandinavismen (Hyvik 2009).

\section{Vegskilje -1868}

Denne diskusjonen rundt kven som kunne kalle seg målstrevar eller ikkje, er eitt av fleire teikn på det vegskiljet som etter kvart skulle bli meir tydeleg. Den underliggande tonen hos Vinje var lenge respekt for språkmannen Knudsen, sjølv om Vinje ikkje alltid var einig i sak. Men i februar 1868 blir tonen ein annan. Vinje skriv ein lang artikkel om målsaka generelt og kor tilspissa og til og med dum (han brukar ordet fåvit) argumentasjonen har blitt i den offentlege debatten. Han nemner mange med namn, og det er nesten med eit hint av desillusjon når han til slutt nemner Knudsen:

Det er sorg-lystig eller tragi-komisk å sjå at for eksempel slike menn som Asbjørnsen og Knudsen, som kvar på sitt vis har gjort, og framleis gjer, så mykje for å fornorske språket vårt, å sjå at desse liksom set den flate handa mot straumen av vatn og seier: Ikkje lenger i dette løpet! her hit i mitt elveleie! At dei ikkje kan lære av Dølen som kallar det han gjer ein milepæl på den lange vegen, eit standpunkt, og er glad for at det blir overvunne (Vinje 1972: III 6b) $)^{21}$.

Her ser me litt av det vegskiljet som har blitt skildra i fleire språkhistoriske gjennomgangar, blant anna hos Hyvik (2009: 342ff) når skiljet mellom landsmålet og andre språkleirar blir tydlegare rundt 1868 . Knudsen tok sjølv initiativ til eit sterkare skilje mellom hans eiga reformline og landsmållina då han gav ut boka Det norske målstraev (1867) som gjennomgåande er ein grenseoppgang mot landsmålet. I tillegg blir 1868 ofte peika på som ein milepæl fordi den organiserte målrørsla for alvor tok fart med opprettinga av Vestmannalaget og Det norske samlaget dette året (Hoel 2011: 29).

I innlegget til Vinje kjem det fram at han meiner Knudsen ikkje vil gå langt nok i å reformere dansken i retning av «det norske». Metaforen med handa til Knudsen som prøver å stoppe ein straum av vatn, seier noko om korleis Vinje såg på den flodbølga av endringar som var på veg, og kor nyttelaust det var å prøve å stoppe dette og si «hit, men ikkje lenger». Der Vinje tidlegare har formulerte seg som om dei

21 «Det er sorg-lystig eller tragi-komisk at sjaa f. Ex. slike Menn som Asbjørnsen og Knudsen, som kver paa sin Vis hava gjort og enno gjera somyket for at fornorske vaart Maal, at sjaa desse liksom setja den flate Loven (indre hule Haand) for straumen og segja: ikke lenger i det Laupet! her hit i mi Flodseng! At dei ikke skulle læra af Dølen, som kallar det, han gjere, ein Milepæl paa den lange Vegen, eit «Standpunct» og er glad i, at det verdt overvunnet!» 
alltid var einige om målet men ueinige om vegen, så kan ein ikkje lenger lese dette inn i formuleringa hans. Her er det klart at dei ikkje lenger deler det same målet.

Ei lita nyansering av dette vegskiljet finn vi likevel same året, hausten 1868 , i det siste av tre lesarinnlegg som Olaus Fjørtoft har i Dølen. Olaus Fjørtoft var målmann, men delte Knudsen sitt prinsipp om ortofon skrivemåte (men dei var ueinige om kva for språkleg varietet eller dialekt skriftspråket skulle rette seg etter).

I lesarinnlegget kjem Fjørtoft med ei nyansering av kor uklare liner det var mellom det som ofte blir kalla dei ulike leirane. Her snakkar han om målmenn som må jobbe saman, anten dei er knudsenske eller aasenske (Vinje, 1972, s. III 147c). Her ser ein altså igjen litt av den gamle tanken om å stå saman om eit felles mål, og Vinje har late dette lesarinnlegget dekke ei heil side i Dølen i desember 1868.

\section{Språksyn}

I juni 1866 inkluderer Vinje eit langt avsnitt frå Knudsen og set på trykk i Dølen. Temaet er tanken om å jobbe for meir språkleg likskap mellom dei tre skandinaviske språka, og det er i tråd med den skandinavismen som fleire slutta seg til på denne tida. Vinje skriv ei lang innleiing der han viser til at Knudsen er «ein lært 'Grammatiker'», og at «Dølen deler ikkje hans standpunkt, men [...] ser at han arbeider mot eit språk som heile Norden siktar mot, nemleg reinsking av sitt eige tungemål og tiljamning av språket slik at det blir meir likt og tilpassa språket i dei to andre nordiske landa» (Vinje 1972: II 248a) ${ }^{22}$.

I innleiinga til Vinje oppsummerer han dessutan ganske greitt essensen i forskjellen på språksynet til dei to på denne måten:

Eg trur at me kunne ha nådd dette dobbelte målet, men ikkje på den utvendige vegen som Knudsen tek, når han nærmast held seg til ei ytre avpruting av bokstavar og skrivemåte. Eg har alltid trudd at me må gå gjennom ei meir indre utvikling av kvart vårt språk slik at me veks meir naturleg saman, heller enn slik handel og vandel med bokstavar ${ }^{23}$.

Begge har tru på ei gradvis endring, men hos Vinje kjem dette som resultat av ei indre drivkraft i språket, i tråd med eit meir romantisk språksyn. Knudsen har for så vidt den same trua på noko naturleg, men den indre drivkrafta ser me ikkje att i hans argumentasjon. Han har derimot større tru på ytre påverknad frå bevisste språkrøktarar. Da vil folk naturleg bruke dei alternativa som dei meiner er best,

22 «Dølen stend ikki på hans Standpunkt, men [...] seer at han arbeider mot eit Maal som heile Norden stevner imot, nemlig Reinsking af sit eiget Tungemaal og ei Tiljavning af det til Likning og Samanstøypning med Maalet i dei andre tvo Nordiske Rike».

23 «Eg trur, at vi kunna naa dette dubbelte Fyremaal, men ikki paa den utvirdest Vegen som Knudsen tek, idet han nærast held seg til ei ytre Afprutning i Bokstavar og Skrivemaate. Eg har altid trutt, at det maa ganga gjenom ei meir indre Utbilding af Kvert vaart Tungemaal, so vi meir naturleg veksa i hop en ved all slik Handel og Vandel med Bokstavar». 
og dermed blir språket endra til det betre. Knudsen formulerer det slik: «Overgangen, her tilnærmingen, må foregå delvis og gradvis. Slik har den nåværende språktilstanden blitt til, og slik må den nyere og bedre, som vi arbeider mot, også bli til» (Vinje 1972: II 248b) ${ }^{24}$.

\section{Teater og økonomi}

Siste gongen Knudsen er nemnt i Dølen, er også i forbindelse med Det norske Theater. Det norske teater hadde hamna i skifteretten, og Knudsen tapa dermed pengar på dette prosjektet som han hadde støtta økonomisk, noko Vinje skriv om i ein artikkel i desember 1868 (Vinje 1972: III 143b). Det står lite i denne artikkelen som seier oss meir om Vinje sitt syn på teaterverksemda til Knudsen, men det bringer oss inn på temaet Vinje, Knudsen og økonomi.

Me skal først gå tilbake til den teksten frå 1865 som me alt har vore innom, der Vinje kjem med mykje skryt, men også litt kritikk som Knudsen tek ille opp. Som del av skrytet blir det nemnt følgande:

[...] han er ein mann som ikkje set skillingen over tanken som så mange andre, men jobbar for vår sak både med pungen og pennen. Han (og ingeniørkaptein Klingenberg) hjalp på den måten Dølen i hans første dagar til å bære noko av tapet sitt (Vinje 1972: II 134c)²5.

Knudsen og Klingenberg hadde altså ikkje bare støtta teateret økonomisk, dei hadde også gitt pengar til Vinje (Vinje kallar seg sjølv ofte for Dølen, så i sitatet ovanfor er det altså ikkje avisa, men personen Vinje det er snakk om). I Jens Brage Halvorsen sitt Norsk Forfatter-Lexikon (1892) er saka også nemnt. Halvorsen skriv følgande om Knudsen:

Dette, i forbindelse med hans uvanleg uegennyttige og oppofrande karakter som har gjort at han har hjelpt fram ein heil del unge menneske til studering, og til å understøtte med betydelige ofre fleire nasjonale formål, slik som det norske Theater og «Dølens» forfatterverksemd, har gjort at han, tross at han er ugift, ikkje har blitt rik tross sine låge krav til livets ytre goder (Halvorsen 1892: 308) ${ }^{26}$.

24 «Overgangen, her tilnærmelsen, må foregå delvis og gradvis. Så har den nuværende språklige tilstand dannet sig, så må den nyere og bedre, som vi nu arbejder hen til, også danne sig».

25 «han er ein Mann, som ikki lik somange seter Skillingen over Tanken, men verkar for vaar Sak baade med Pungen og Pennen. Han (og Ingenieurkaptein Klingenberg) hjælpte soleides Dølen i hans første Dagar til at bera med nokot af Tapet hans».

26 «Dette i Forbindelse med hans overmaade uegennyttige og opofrende karakter, som har bragt ham til at hjælpe frem en hel Del unge Mennester til Studeringer og til at understøtte med betydelige Ofre flere nationale Formaal, saasom det norske Theater og 'Dølens' Forfattervirksomhed, har gjort, at han, uagtet ugift, ikke er bleven formuende trods sine smaa Fordringer til Livets udvortes Goder». 
Jens Brage Halvorsen var biblioteksmann og journalist ${ }^{27}$, og han var i same omgangskrets som Vinje og Knudsen og kjente begge to. Knudsen skriv i sine Optegnelser (sitert hos Johnsen 2006) at nokre av notata hans med oversikt over utgjevingar har nl. i flere måneder vort hos J.B. Halvorsen til bruk for hans Forfatter-lexicon (Johnsen 2006: 401). Dei var altså godt kjente, og Halvorsen må ha hatt god oversikt over Knudsen og hans bedrifter. I same leksikon, under oppslaget om Vinje er saka også nemnt på denne måten:

Etter to år ga han derfor foreløpig opp Dølen. Han hadde da, etter det han forteller, «tapt flere hundre daler», et tap som overlærer Knudsen og ingeniørkaptein Klingenberg hjamlp ham med å bære (Halvorsen 1892: 142) ${ }^{28}$.

Det står ikkje noko meir nøyaktig om beløpet, men ein kan lure på om det kan ha vore støtte av ein viss storleik ettersom Halvorsen brukar bare det norske Theater og «Dølens» forfatterverksemd som sine to døme på betydelige ofre til nasjonale formål. Det står lite om bakgrunnen for ei slik pengestøtte, men det er enda eit døme på at det var mange ting som batt Knudsen og Vinje saman.

Kanskje var det eit uttrykk for dette at dei trass alt kjempa ein felles kamp for norsken. Det var verdt å støtte kvarandre sjølv om ein hadde noko ulike haldning til språklege vegval.

\section{Avslutning}

Når ein fokuserer på Vinje og Knudsen i samanheng, ser ein at dei har mange overlappande haldningar og syn på dei store linene i språkdebatten. Tilvisingane som Vinje har til Knudsen i Dølen, viser først og fremst ein raud tråd av respekt for språkmannen Knudsen. Sjølv om Vinje kan uttale seg kvast og direkte om mange av motstandarane sine, er det alltid ein viss «mild overbærenhet» når han uttaler seg om Knudsen, slik Vinje-biografen Johnsen formulerer seg om forholdet mellom dei to (Johnsen 2006: 222).

I dei store spørsmåla ser dei to ofte på kvarandre som meiningsfeller. Dei ønskte eit norsk skriftspråk som klart skilde seg frå dansk, med norsk vokabular og norsk uttale. Dei ønska reform av innhaldet i skulen. Dei delte syn på korleis ein kunne jobbe med scenespråket på norske teater. Og i tillegg fekk også Dølen, det store avisprosjektet til Vinje, økonomisk støtte frå Knudsen, sannsynlegvis ganske stor.

Likevel har eg trekt fram at dei etter kvart definerte seg meir vekk frå kvarandre. Dei starta begge med å seie at dei hadde eit felles mål, men både Knudsen og Vinje

27 Sjå oversikt over verksemda til Halvorsen i Norsk biografisk leksikon.

28 «Efter to Aars Forløb opgav ham derfor foreløbig Dølen; han havde da, efter hva han fortæller, 'tapat fleire hundrar Daler,' - et Tab, som Overlærer K. Knudsen og Ingeniørkaptein J.B. Klingenberg hjalp ham med at bære». 
uttrykker seg annleis mot slutten av 1860-talet. Dei jobba etter kvart mot ulike mål. Den store konfrontasjonen mellom dei kjem likevel aldri. Kanskje er det så enkelt som at dei kjem frå nokolunde lik bakgrunn. I Knudsens Livsminner får me eit glimt av at Knudsen uttrykker ei slik kjensle av fellesskap med Vinje når han fortel om ei samtale med «en av våre hæveste professorer». Professoren meinte at Vinje var mindre påliteleg enn han burde vere, og at dette hang saman med noko lågborgerligt hos Vinje som han meinte kom av at «Dølen hadde fåt sit ophav fra en husmansstue» (Knudsen 1937: 30). Knudsen meiner at ein ikkje kunne trekke ei slik slutning basert på denne bakgrunnen til Vinje, og han går gjennom sin eigen bakgrunn med gardbrukarar både på mors- og farssida (Knudsen 1937: 31) og viser slik at han identifiserer seg sjølv med bakgrunnen til Vinje.

Dei vil bli ståande som del av historia til kvart sitt skriftspråk, men dei hadde mange ulike fellestrekk på svært mange område. Eg har gjort eit utsnitt av noko av det dei to skreiv og korleis dei kommenterte kvarandre. Dette utsnittet viser at det er mange nyansar i forholdet mellom dei som kanskje forsvinner litt når ein i språkhistoriske framstillingar nærmast deler historia i to.

\section{Litteraturliste}

Almenningen, O., T.A. Roksvold, H. Sandøy og L.S. Vikør. (1981). Språk og samfunn gjennom tusen år. Oslo: Universitetsforl.

Bjørkli, L.S.R. (2011). På godt norsk! Avløserord hos Vinje i et synkront perspektiv. Masteroppgave: Universitetet i Oslo.

Bleken, B. (1956). Studier i Knud Knudsens grammatiske arbeider. Bd. 14. Oslo: I kommisjon hos Aschehoug.

Bull, E., A. Krogvig og G. Gran. (1936). Norsk biografisk leksikon. Bd. 7: Jensen, Lars O.-Krefting. Oslo: Aschehoug.

Dahl, H. (1962). Knud Knudsen og latinskolen. Oslo: Universitetsforlaget.

Halvorsen, J.B. (1892). Norsk Forfatter-Lexikon 1814-1880. Kristiania: Den Norske Forlagsforening. Haugen, E. (1969). Riksspråk og folkemål. Oslo: Universitetsforlaget.

Hertzberg, F. (1995). Norsk grammatikkdebatt i historisk lys. Oslo: Novus.

Hoel, O.L. (1996). Nasjonalisme i norsk målstrid 1848-1865. Oslo: Noregs forskingsråd.

Hoel, O.L. (2011). Norsk målreising. Bd. 2: Mål og modernisering 1868-1940. Oslo: Samlaget.

Hovdhaugen, E., F. Karlson, C. Henriksen og B. Sigurd. (2000). The History of linguistics in the Nordic countries. Helsinki: Societas Scientiarum Fennica.

Hyvik, J.J. (2009). Norsk målreising. Bd. 1: Språk og nasjon 1739-1868. Oslo: Samlaget.

Johnsen, E.B. (2006). Unorsk og norsk. Knud Knudsen: en beretning om bokmålets far. Tvedestrand: Bokbyen forl.

Knudsen, K. (1850). Om norskhed i vor tale og skrift. Nor, Norsk tidsskrift for videnskab og litteratur, s. 205-273.

Knudsen, K. (1862). Er Norsk det samme som Dansk? Kristiania: Det Steenske Bogtrykkeri.

Knudsen, K. (1867). Det norske målstræev. Kristiania: Brøgger \& Christie.

Knudsen, K. (1876). landsgyldige norske uttale. Kristiania: K. Knudsen.

Knudsen, K. (1881). Unorsk og norsk, eller Fremmedords avløsning. Bd. 2. Kristiania: Cammermeyer.

Knudsen, K. (1884). Latinskole uten latin. Kristiania: A.W. Brøgger.

Knudsen, K. (1937). Knud Knudsens livsminner: barneår og ungdomsår. Oslo: Aschehoug. 
Knudsen, K. (1956). Haandbog i dansk-norsk sprogloere. Kristiania: J.Chr. Abelstad.

Morgenbladet. (1864). Morgenbladet, 29. desember 1864. https://urn.nb.no/URN:NBN:no-nb_ digavis_morgenbladet_null_null_18641231_46_360_1 (tilgang: 10.09.2021)

Otnes, H. og B. Aamotsbakken. (2017). Tekst i tid og rom. Norsk språkhistorie. Oslo: Det norske samlaget.

Skard, S. (1938). A.O. Vinje og antikken: Studier i norsk åndshistorie. Oslo: Det Norske videnskaps-akademi.

Torp, A. og L.S. Vikør. (2014). Hovuddrag i norsk språkhistorie. 4. utg. Oslo: Gyldendal akademisk. Vesaas, O. (2018). A.O. Vinje: ein tankens hoermann. Oslo: Cappelen Damm.

Vinje, A.O. (red.). (1972). Dølen: eit vikublad: 1858-1870. Oslo: Noreg Boklag. 